\title{
Analysis of Factors Affecting Teacher Performance in State Junior High School Learning in Bengkalis Regency
}

Melly Miranda*, Almasdi Syahza, Sumarno

Faculty of Teacher Training and Education, Pekanbaru, 28293, Indonesia

\section{ARTICLE INFO}

Article history:

Received: 10 Dec 2020

Revised: 21 June 2021

Accepted: 27 June 2021

Published online: 24 July 2021

\section{Keywords:}

Work Climate

Work Motivation

Job Satisfaction

Teacher Performance

\begin{abstract}
A B S T R A C T
This study aims to analyze the factors that influence the performance of teachers in learning SMP Negeri in Bengkalis Regency. The population sample in this study is amounted to 56 people. They are all teachers who are Civil Servants who teach at Bengkalis Regency Public Junior High Schools consisting of Public Junior High Schools in Bukit Batu District and State Junior High Schools in Bandar Laksamana District. Data was collected using a questionnaire. The data analysis used in this research is descriptive quantitative and path analysis. The results of the study show: 1) the work climate has an effect on teacher job satisfaction by $43.1 \%$; 2) work motivation has an effect on teacher job satisfaction by $42.5 \%$; 3) work climate has an effect on teacher performance by $35.3 \%$; 4) work motivation has an effect on teacher performance by $32.7 \%$; 5) job satisfaction has an effect on teacher performance by $26.0 \%$; 6) work climate has an effect on teacher performance through job satisfaction of $11.2 \%$; 7) work motivation has an effect on teacher performance through job satisfaction of $11.0 \%$. The meaning is that if the work climate has good quality, is comfortable, and pleasant, it will lead to satisfaction for a teacher, and this will trigger the teacher's enthusiasm in teaching which will have an impact on improving teacher performance.
\end{abstract}

\section{Introduction}

The success of an organization is largely determined by the quality of the human resources in it. Therefore, the role of qualified human resources is very much needed for the advancement of technology and the development of information. One of the components of human resources in educational organizations is the teacher. Teachers are one of the pillars that determine the success of educational activities in schools.

\footnotetext{
${ }^{*}$ Corresponding author. 
As a component that supports the success of the learning process, the performance of a teacher must always be maintained and improved. Educational goals will be difficult to achieve if teacher performance is low. According to Sumarno (2012) in school organizations, learning is not only important for students, but also for everyone involved in the school (especially teachers and principals) so that they can adapt to the demands of changing society.

In order to create professional teachers, the government has made rules for the requirements to become teachers. To make teachers professional, it is necessary to hold continuous and continuous coaching, and make teachers as educators who need to be considered, appreciated and recognized for their professionalism (Naziah et al., 2020). To make them professional, it is not only to increase their competence either through the provision of upgrading, training, or get the opportunity to learn again, but also to pay attention to teachers from other aspects such as increasing discipline, working climate conditions, providing motivation, providing guidance through supervision, providing incentives, decent salaries, thus enabling teachers to be satisfied in working as educators. Professional teachers are expected to be able to provide quality learning to students in the classroom (Desmita et al., 2021).

Based on the results of observations in several public junior high schools in Bengkalis Regency, namely Public Junior High Schools in Bukit Batu District and Public Junior High Schools in Bandar Laksamana District, there are still many problems with teacher performance in learning. Less than optimal teacher performance can be seen from the presence of some teachers who have not made learning preparations before teaching. Another problem that shows the less than optimal performance of teachers in learning is shown by the number of teachers who have not used various learning methods.

The next problem is seen from some teachers still delivering material in a way that is less interesting in delivering learning. This can be seen from the teachers who have not fully optimized the use of school facilities such as LCDs and the internet. In addition, other problems can be seen from the teacher who has not been able to condition the class situation to be calm when there are students who make noise in class. Another problem can be seen from when the teacher is not present and does not give assignments to the picket teacher for student learning. So that the performance of teachers in the discipline of work is not yet optimal.

Teacher performance is important in education, and is a determinant of the level of quality of education. Good teacher performance can be seen from how many competencies needed are met (Febriana et al., 2020). If the teacher's performance increases, it will affect the quality of the output, therefore there needs to be support from various schools to improve teacher performance. According to Syahza (2013), teacher performance is a work ability or work performance shown by a teacher to obtain optimal work results. According to Setiawan (2018) teacher performance can be influenced by several factors, both factors that come from within the teacher (internal) and factors that come from outside the teacher (external). 
Teacher job satisfaction is a factor that must be considered by management as an effort to maintain the desired level of teacher performance. This is in line with research conducted by (Pamungkas et al., 2014) which explains that job satisfaction affects teacher performance. The higher the teacher's job satisfaction, the higher the teacher's performance. This is also reinforced by research conducted by Utami (2017) which explains that teacher job satisfaction needs to be considered because teachers who feel satisfied at work will have better performance compared to teachers who feel dissatisfied at work.

Sutrisno (2008) suggests that job satisfaction is a pleasant or unpleasant emotional state, with which employees view their work. This can be seen in the positive attitude of employees towards work and everything that is encountered in the work environment. According to Supardi (2014) the work climate is a place where teachers carry out their daily work which includes lighting, coloring, sound, air, cleanliness, security, and spatial planning. According to Siagian (2009) work motivation is a condition that encourages a person to carry out his work to achieve organizational goals and individual goals.

This is in line with research conducted by Badawi (2014) explaining that the work climate provides the greatest contribution to teacher job satisfaction, thus the work climate is the main element in increasing teacher job satisfaction, so there needs to be various improvements and various actions that should be taken in efforts to develop and improve the work climate. Therefore, the better the work climate in the school, the higher the teacher's satisfaction.

This study also explains that the higher and more dynamic the work motivation of teachers, the more significant it will be to increase teacher job satisfaction. Thus, teacher work motivation provides the second largest contribution to increasing teacher job satisfaction. This is also reinforced by research conducted by Sulaefi (2018) explaining that motivation is the provision of a driving force that creates a person's enthusiasm for work so that they want to work together, work effectively and be integrated with all their efforts to achieve job satisfaction. It can be concluded that work motivation makes a real contribution and has a significant influence on job satisfaction. Based on the description that has been put forward, this research is important to be carried out with the aim of analyzing the factors that affect teacher performance in learning at State Junior High Schools in Bengkalis Regency.

\section{Methodology}

This research used quantitative descriptive which aims to analyze the factors that influence teacher performance in learning at State Junior High Schools in Bengkalis Regency. The sample in this study were all teachers with the status of Civil Servants who teach at Bengkalis District Junior High Schools consisting of 56 State Junior High Schools in Bukit Batu District and Public Junior High Schools in Bandar Laksamana District. The data collection method used is the questionnaire method. The questionnaire method was compiled using a Likert 
scale model with an ordinal measurement scale. In processing the data, the ordinal scale is transformed to an interval scale.

The validity test was measured using the Corrected Item-Total Correlation with the help of the SPSS version 23 program. The test results of the instrument were 37 statements that had been tested on 54 respondents, after testing the validity and reliability two statements were declared invalid and the reliability test used the Cronbach's Alpha formula. The research data was tested with the prerequisite analysis test, namely the normality test. The data analysis technique in this research is quantitative descriptive analysis using frequency distribution and data analysis for research data processing using path analysis. According to Heryanto \& Trwibowo (2018) path analysis is a technique for analyzing causal relationships that occur in multiple regression if the independent variable affects the dependent variable not only directly but also indirectly. The data analysis technique uses path analysis with substructures presented in Figure 1.

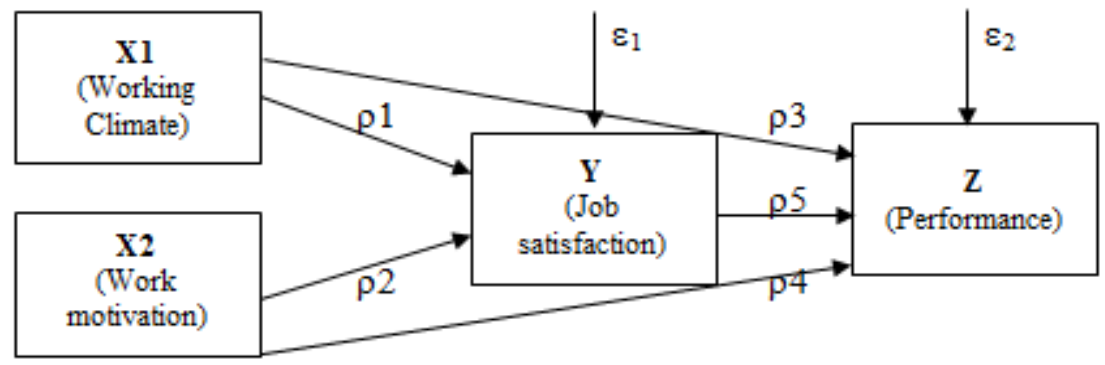

Figure 1. Conceptual Design of Work Climate and Work Motivation on Job Satisfaction and Work Climate, Work Motivation and Job Satisfaction on Performance

According to Figure 1. the following two equations are obtained:

With the equation $\mathrm{Y}=\rho 1 \mathrm{X} 1+\rho 1 \mathrm{X} 2+\varepsilon_{1}$

With the equation $Z=\rho 3 X 1+\rho 4 X 2+\rho 5 Y+\varepsilon_{2}$

The following is a description of the indicators for each variable as presented in Table 1.

Table 1. Operationalization of Research Variables

\begin{tabular}{|c|c|c|}
\hline Variabel & Operational definition & Indicator and Item No. \\
\hline $\begin{array}{c}\text { Teacher } \\
\text { Performance }\end{array}$ & $\begin{array}{l}\text { Teacher performance is the } \\
\text { result of work / work } \\
\text { achievements that have been } \\
\text { achieved by a teacher in } \\
\text { learning to achieve educational } \\
\text { goals. }\end{array}$ & $\begin{array}{l}\text { 1. Lesson planning (1) } \\
\text { 2. Implementation of learning activities } \\
(2,3,4,5,6,7,8,9) \\
\text { 3. Learning assessment (10) }\end{array}$ \\
\hline Job satisfaction & $\begin{array}{l}\text { Job satisfaction is the attitude } \\
\text { of a teacher towards his work } \\
\text { as a pleasant or unpleasant } \\
\text { thing based on the suitability } \\
\text { between what is given and }\end{array}$ & $\begin{array}{l}\text { 1. The work itself }(1,2,3) \\
\text { 2. Salary }(4.5) \\
\text { 3. Promotion opportunities }(6,7,8) \\
\text { 4. Supervision }(9.10) \\
\text { 5. Partner }(11,12)\end{array}$ \\
\hline
\end{tabular}




\begin{tabular}{cll}
\hline & & \\
\hline $\begin{array}{c}\text { Working } \\
\text { Climate }\end{array}$ & $\begin{array}{l}\text { The work climate is the } \\
\text { condition of the work } \\
\text { environment that is felt directly } \\
\text { by the teacher in carrying out } \\
\text { tasks at school. }\end{array}$ & $\begin{array}{l}\text { 1. Physical work environment }(13,14,15) \\
(16,17)\end{array}$ \\
\hline $\begin{array}{l}\text { Work } \\
\text { motivation }\end{array}$ & $\begin{array}{l}\text { Work motivation is a condition } \\
\text { that exists in a teacher to carry } \\
\text { out activities within the scope } \\
\text { of his work as an effort to } \\
\text { achieve personal and } \\
\text { organizational goals. }\end{array}$ & $\begin{array}{l}\text { 1. Responsibility in doing work } \\
\text { (18,19,20) }\end{array}$ \\
& $\begin{array}{l}\text { 2. Achievements }(21,22,23) \\
\text { 4. Self-development }(24.25)\end{array}$ \\
\hline
\end{tabular}

\section{Results and Discussion}

\section{Descriptive Statistical Analysis Results}

The results of descriptive statistics will be divided into 5 categories, namely very high, high, medium, low, and very low categories. The following are the results of the descriptive statistics of each variable.

\section{a. Job Satisfaction Variable (Y)}

Data obtained based on a questionnaire given to respondents as many as 11 statement items using a Likert scale with choices 1 to 4 . The highest score is 44 and the lowest score is 11 . In the job satisfaction variable there are 5 indicators, namely: the job itself, salary, promotion opportunities , and partners. Based on the data from the research results, it can be seen that the frequency distribution of teacher job satisfaction levels is in Table 2.

Table 2. Frequency Distribution of Teacher Job Satisfaction Levels

\begin{tabular}{clcccc}
\hline No & & Category & Interval & F & \% \\
\hline 1 & Very high & $37,4-44$ & 29 & 53,7 \\
2 & High & $30,8-36,4$ & 20 & 37,0 \\
3 & Medium & $24,2-29,8$ & 5 & 9,3 \\
4 & Low & $17,6-23,2$ & - & - \\
5 & Very low & $11-16,6$ & - & - \\
\hline & & & 54 & 100 \\
\hline
\end{tabular}

From Table 2 it can be seen that most of the job satisfaction of State Junior High School teachers in Bengkalis Regency is in the very high category with a frequency of 29 respondents with an average of $53.7 \%$. However, there are still 5 respondents with an average of $9.3 \%$ in the medium category. This is because in the questionnaire statement item number 7 there are 2 teachers who stated that they were not satisfied if the assessment for promotion was based on the teacher's achievements and work results. And the questionnaire statement item number 8 contained 13 teachers who expressed doubts if promotions in the work environment were carried out fairly, democratically, and transparently. Based on these data, it can be seen that in general the job satisfaction of public junior high school teachers in Bengkalis Regency is quite high. 
b. Work Climate Variable (X1)

Data was obtained based on a questionnaire given to respondents as many as 5 statement items using a Likert scale with choices from 1 to 4 . The highest score was 20 and the lowest score was 5 . In the work climate variable there were 2 indicators, namely: physical environment and non-physical environment. Based on the data from the research results, it can be seen that the frequency distribution of the teacher's work climate level is in Table 3.

Table 3. Frequency Distribution of Teachers' Work Climate Levels

\begin{tabular}{clcccc}
\hline No & & Category & Interval & F & \% \\
\hline 1 & Very high & $17-20$ & 23 & 42,6 \\
2 & High & $14-16$ & 21 & 38,9 \\
3 & Medium & $11-13$ & 10 & 18,5 \\
4 & Low & $8-10$ & - & - \\
5 & Very low & $5-7$ & - & - \\
\hline & & & 54 & 100 \\
\hline
\end{tabular}

From Table 3, it can be seen that most of the work climates of public junior high school teachers in Bengkalis Regency are in the very high category with a frequency of 23 respondents with an average of $42.6 \%$. However, there are still 10 respondents with an average of $18.5 \%$ in the medium category. This is because in the questionnaire statement item number 1 there are 9 teachers who state that they are quite good for learning facilities and infrastructure in schools. And the questionnaire statement item number 15 contained 8 teachers who stated that it was good enough for security at school. Based on these data, it can be seen that in general the working climate of public junior high school teachers in Bengkalis Regency is quite high.

\section{c. Work Motivation Variable (X2)}

Data were obtained based on a questionnaire given to respondents as many as 10 statement items using a Likert scale with choices from 1 to 4 . The highest score was 40 and the lowest score was 10 . In the work motivation variable there are 4 indicators, namely: responsibility in doing work, achievement achieved, selfdevelopment, and the ability to act. Based on the data from the research results, it can be seen that the frequency distribution of the teacher's work motivation level is in Table 4.

Table 4. Frequency Distribution of Teachers' Work Motivation Levels

\begin{tabular}{|c|c|c|c|c|}
\hline No & Category & Interval & $\mathbf{F}$ & $\%$ \\
\hline 1 & Very high & $34-40$ & 26 & 48,1 \\
\hline 2 & High & $28-33$ & 20 & 37,0 \\
\hline 3 & Medium & $22-27$ & 8 & 14,9 \\
\hline 4 & Low & $16-21$ & - & - \\
\hline 5 & Very low & $10-15$ & - & - \\
\hline \multicolumn{3}{|c|}{ Total } & 54 & 100 \\
\hline
\end{tabular}


From Table 4 it can be seen that most of the work motivation of State Junior High School teachers in Bengkalis Regency is in the very high category with a frequency of 26 respondents with an average of $48.1 \%$. However, there are still 8 respondents with an average of $14.9 \%$ in the medium category. This is because in the questionnaire statement item number 23 there are 2 teachers who state that they have never tried to exceed their friends in doing competitive tasks. And the questionnaire statement item number 26 contained 9 teachers who stated sometimes to work independently without depending on others. Based on these data, it can be seen that in general the work motivation of public junior high school teachers in Bengkalis Regency is quite high.

\section{d. Performance Variable (Z)}

Data were obtained based on a questionnaire given to respondents as many as 9 statement items using a Likert scale with choices from 1 to 4 . The highest score was 36 and the lowest score was 9 . In the teacher performance variable there were 3 indicators, namely: learning planning, implementation of learning activities, and learning assessment. Based on the data from the research results, it can be seen the frequency distribution of the teacher's performance level in Table 5.

Table 5. Frequency Distribution of Teacher Performance Levels

\begin{tabular}{clcccc}
\hline No & & Category & Interval & F & \% \\
\hline 1 & Very high & $30,6-36$ & 29 & 53,7 \\
2 & High & $25,2-29,6$ & 21 & 38,9 \\
3 & Medium & $19,8-24,2$ & 4 & 7,4 \\
4 & Low & $14,4-18,8$ & - & - \\
5 & Very low & $9-13,4$ & - & - \\
\hline & & & 54 & 100 \\
\hline
\end{tabular}

From Table 5, it can be seen that most of the performance of public junior high school teachers in Bengkalis Regency are in the very high category with a frequency of 29 respondents each with an average of 53.7\%. However, there are still 4 respondents with an average of $7.4 \%$ in the medium category. This is because in the questionnaire statement item number 1 there are 43 teachers categorized as very good by the principal for planning their learning. And the questionnaire statement item number 2 and number 9 each contained 24 teachers who were categorized as very good by the principal for apperception and closing learning in the implementation of learning activities. Based on these data, it can be seen that in general the performance of public junior high school teachers in Bengkalis Regency is quite high.

\section{Path Analysis}

\section{Structure Path Analysis 1}

The effect of work climate (X1) and work motivation (X2) on job satisfaction (Y) is shown in Table 6. 
Table 6. Analysis of Structure Paths 1

\begin{tabular}{lccc}
\hline \multicolumn{1}{c}{ Variabel } & $\begin{array}{c}\text { Koefisien } \\
\text { Jalur }\end{array}$ & Sig. & $\begin{array}{c}\mathbf{R} \\
\text { Square }\end{array}$ \\
\hline Working Climate & 0,431 & 0.001 & 0,594 \\
Work motivation & 0,425 & 0,001 & \\
a. Dependent Variable: job satisfaction & & \\
\hline
\end{tabular}

Based on Table 6 obtained Sig. $0.001<0.05$, meaning that the work climate and work motivation have a significant effect on job satisfaction of State Junior High School teachers in Bengkalis Regency. The magnitude of the influence of work climate and work motivation has a significant effect on job satisfaction of State Junior High School teachers in Bengkalis Regency is 0.594 (59.4\%). R Square value of 0.594 can be calculated the magnitude of the residual coefficient as follows:

$\varepsilon=\sqrt{1-R^{2}}=\sqrt{1-0,594}=0.229$

Based on the calculation of the path coefficients in Table 6 and the calculation of the residuals/errors mentioned above, the $\mathrm{X} 1$ and $\mathrm{X} 2 \rightarrow \mathrm{Y}$ path relationships can be described as follows:

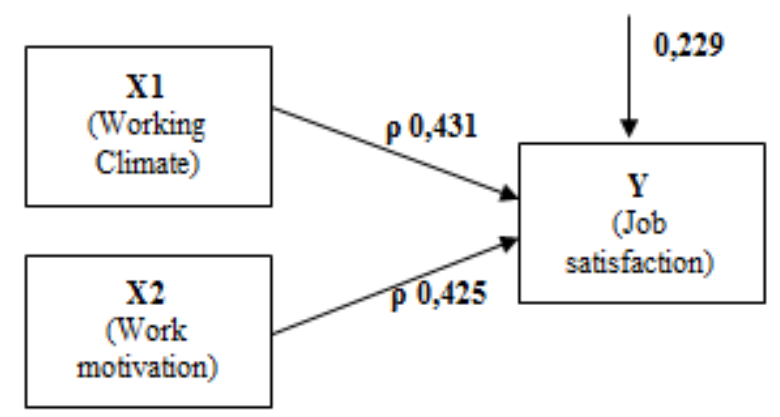

Figure 2. The Effect of Work Climate (X1), Work Motivation (X2) on Job Satisfaction (Y)

From Figure 2, it can be seen that the structural path equation 1 is as follows:

$\mathrm{Y}=0.431 \mathrm{X} 1+0.425 \mathrm{X} 2+0.229$

This means that the equation shows that:

1. The coefficient value of the work climate variable (X1) is 0.431 . This means that every 1 unit increase in the work climate will increase the job satisfaction of State Junior High School teachers in Bengkalis Regency by 0.431 .

2. The coefficient value of the work motivation variable (X2) is 0.425 . This means that every 1 unit increase in work motivation will increase the job satisfaction of State Junior High School teachers in Bengkalis Regency by 0.425 .

3. The standard error (e1) is 0.229 , meaning that the magnitude of the error path coefficient for other variables outside this study that affects the job 
satisfaction of State Junior High School teachers in Bengkalis Regency is 0.229 or $22.9 \%$.

\section{Structure Path Analysis 2}

The effect of work climate (X1) and work motivation (X2), and job satisfaction (Y) on performance $(\mathrm{Z})$ is shown in table 7.

Table 7. Analysis of Structure Paths 2

\begin{tabular}{lccc}
\hline Variabel & $\begin{array}{c}\text { Koefisien } \\
\text { Jalur }\end{array}$ & Sig. & $\begin{array}{c}\boldsymbol{R} \\
\text { Square }\end{array}$ \\
\hline Working Climate & 0,353 & 0.006 & 0,637 \\
Work motivation & 0,327 & 0,011 & \\
Job satisfaction & 0,260 & 0,028 & \\
a. Dependent Variable: teacher performance & & \\
\hline
\end{tabular}

Based on Table 7 obtained Sig. $0.006<0.05$, meaning that the work climate has a significant effect on the performance of State Junior High School teachers in Bengkalis Regency. Sig. $0.011<0.05$, meaning that work motivation has a significant effect on the performance of State Junior High School teachers in Bengkalis Regency. Sig. $0.028<0.05$, meaning that job satisfaction has a significant effect on the performance of State Junior High School teachers in Bengkalis Regency. The magnitude of the influence of work climate, work motivation, and job satisfaction have a significant effect on the performance of State Junior High School teachers in Bengkalis Regency is 0.637 (63.7\%). R Square value of 0.637 can be calculated the magnitude of the residual coefficient as follows:

$\varepsilon=\sqrt{1-R^{2}}=\sqrt{1-0,637}=0.202$

Based on the calculation of the path coefficients in Table 7 and the calculation of the residuals/errors mentioned above, the path relationship $\mathrm{X} 1-\mathrm{Z}, \mathrm{X} 2-\mathrm{Z}$ and the Y1 - Z relationship can be described as follows:

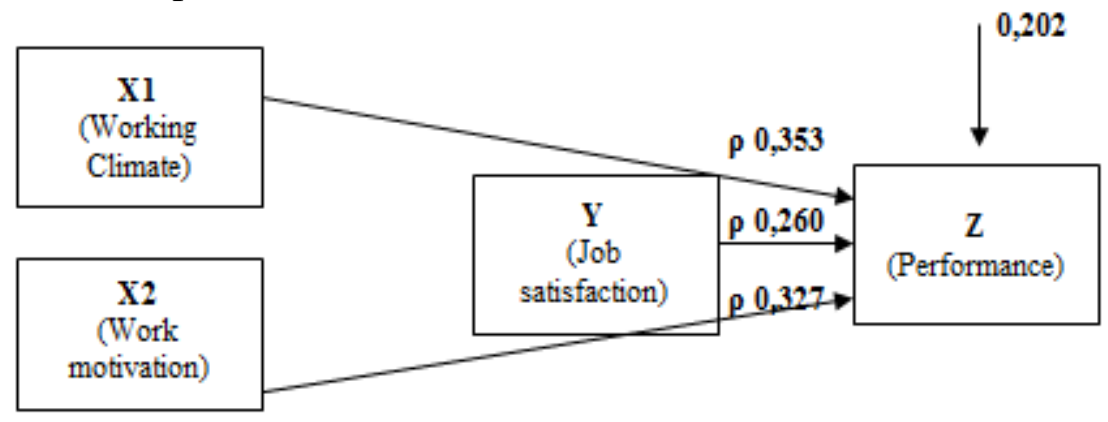

Figure 3. The Effect of Work Climate (X1), Work Motivation (X2) and Job Satisfaction (Y1) on Performance (Z)

From Figure 3, it can be seen that the equation for structural path 2 is as follows:

$\mathrm{Z}=0.353 \mathrm{X} 1+0.327 \mathrm{X} 2+0.260 \mathrm{Y}+0.202$ 
This means that the equation shows that:

1. The coefficient value of the work climate variable (X1) is 0.353 . This means that every 1 unit increase in the work climate will increase the performance of State Junior High School teachers in Bengkalis Regency by 0.353 .

2. The coefficient of work motivation variable (X2) is 0.327 . This means that every increase in work motivation by 1 unit will increase the performance of State Junior High School teachers in Bengkalis Regency by 0.327.

3. The coefficient value of the job satisfaction variable (Y) is 0.260 . This means that every increase in job satisfaction by 1 unit will increase the performance of State Junior High School teachers in Bengkalis Regency by 0.260 .

4. The standard error (e2) is 0.284 , meaning that the magnitude of the error path coefficient for other variables outside this study that affects the performance of State Junior High School teachers in Bengkalis Regency is 0.202 or $20.2 \%$

\section{Joint Path Analysis of Structure 1 and Structure 2}

The following will present a combination of the structure path diagram 1 and the structure path diagram 2 which can be described as follows:

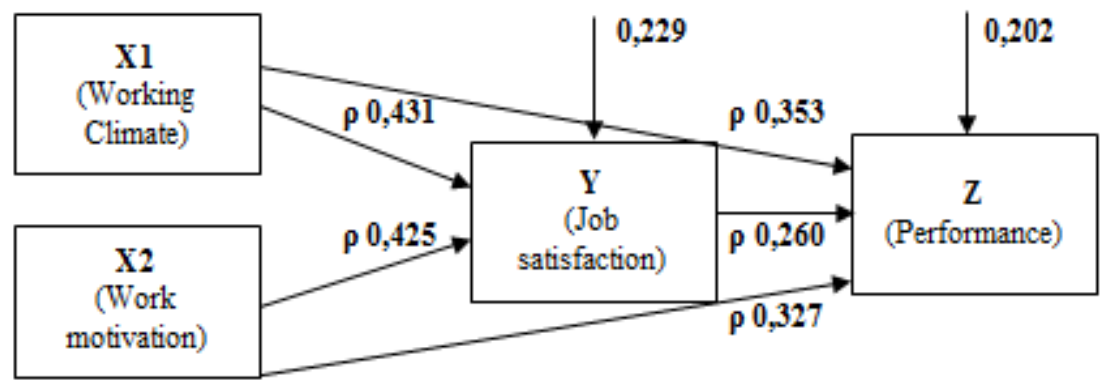

Figure 4. Combined Structural Analysis 1 and Structural Analysis 2

Based on Figure 4, it is known that the work climate (X1), work motivation (X2), and job satisfaction (Y) have a significant effect on performance (Z) either directly or indirectly. The following describes the calculations both directly and indirectly between variables shown in Table 8 .

Table 8. Direct and Indirect Effects between Variables

\begin{tabular}{cccc}
\hline Variabel & $\begin{array}{c}\text { Direct } \\
\text { Influence }\end{array}$ & $\begin{array}{c}\text { Indirect } \\
\text { Influence }\end{array}$ & $\begin{array}{c}\text { Total } \\
\text { Influence }\end{array}$ \\
\hline $\mathrm{X} 1-\mathrm{Y}$ & 0.431 & - & 0.431 \\
$\mathrm{X} 2-\mathrm{Y}$ & 0.425 & - & 0.425 \\
$\mathrm{X} 1-\mathrm{Z}$ & 0.353 & $0.431 \times 0.260=0.112$ & $0,353+0,112=0.465$ \\
$\mathrm{X} 2-\mathrm{Z}$ & 0.327 & $0,425 \times 0,260=0,110$ & $0,327+0,110=0,437$ \\
$\mathrm{Y} 1-\mathrm{Z}$ & 0.260 & - & 0.260 \\
\hline
\end{tabular}


Based on Table 8 shows that:

\section{Indirect Influence}

a. The coefficient value of the indirect influence of work climate variables on teacher performance through job satisfaction of State Junior High School teachers in Bengkalis Regency is 0.112 or $11.2 \%$.

b. The value of the coefficient of the indirect effect of work motivation on teacher performance through the job satisfaction of State Junior High School teachers in Bengkalis Regency is 0.110 or $11.0 \%$.

\section{Total Influence}

a. The coefficient value of the total influence of work motivation variables on teacher performance through job satisfaction of State Junior High School teachers in Bengkalis Regency is 0.465 or $46.5 \%$.

b. The coefficient value of the total influence of work motivation variables on teacher performance through job satisfaction of State Junior High School teachers in Bengkalis Regency is 0.437 or $43.7 \%$.

\section{a. Effect of Work Climate (X1) on Job Satisfaction (Y)}

Based on the data analysis and hypothesis testing that have been carried out in this study, the results showed that there was a significant influence between work climate on job satisfaction. The work climate can affect job satisfaction, this is because job satisfaction is an external factor that is needed so that the comfort of teachers in teaching can be achieved, both in the physical environment and in the non-physical environment.

The work environment is a place where teachers interact and have activities in their daily lives, therefore teachers cannot be separated from the close influence of the surrounding environment. According to (Armani et al., 2017) if a conducive work environment is created, the teacher will feel satisfied and the teacher will be comfortable in carrying out his duties. The suitability of the work environment can provide its own job satisfaction for teachers.

The physical work environment is really needed by the teacher to get comfortable in all the processes in the school which will have an impact on a good teaching and learning process. While the non-physical work environment is more towards social relations in schools, namely the relationship between superiors and teachers, between teachers and teachers and employees.

\section{b. The Effect of Work Motivation (X2) on Job Satisfaction (Y)}

Based on data analysis and hypothesis testing that have been carried out in this study, the results showed that there was a significant influence between work 
motivation and job satisfaction. The level of work motivation is very influential on job satisfaction that can be achieved by teachers. High work motivation will encourage the work spirit of teachers to complete their tasks. According to Sulaefi (2018), motivation is the provision of a driving force that creates one's work enthusiasm, so that they are willing to work together, work effectively and are integrated with all their efforts to achieve job satisfaction.

Motivation can be interpreted as a condition or action that encourages teachers to do their job as much as possible. Teachers who have low motivation will tend to display feelings of discomfort and displeasure with their work. If the teacher is satisfied, then the teacher will work with enthusiasm.

\section{c. Effect of Work Climate (X1) on Performance (Z)}

Based on data analysis and hypothesis testing that have been carried out in this study, the results showed that there was a significant influence between work climate on performance. The work environment is a place where teachers interact and have activities in their daily lives, therefore teachers cannot be separated from the close influence of the surrounding environment. The physical work environment is very much needed by the teacher to get comfortable in all the processes in the school which will have an impact on a good teaching and learning process. While the non-physical work environment is more towards social relations in schools, namely the relationship between superiors and teachers, between teachers and teachers and employees.

Environmental conditions are said to be good if humans can carry out activities optimally, healthy, safe, and comfortable. If the work environment can support a teacher to do a better job, then the teacher will carry out teaching and learning activities optimally so that teacher performance will increase because it is supported by a conducive work environment.

\section{d. The Effect of Work Motivation (X2) on Performance (Z)}

Based on data analysis and hypothesis testing that have been carried out in this study, the results showed that there was a significant influence between work motivation on performance. Teachers who have high work motivation will be motivated or compelled to do a job better than teachers who have low levels of motivation. Teachers need to have high work motivation to achieve school goals. Teachers who have high work motivation will be more enthusiastic in carrying out their work. Teachers who have high work motivation will always work hard to overcome all kinds of problems faced in the hope of achieving better results. The higher the teacher's work motivation, the higher the teacher's performance.

\section{e. Effect of Job Satisfaction (Y) on Performance (Z)}

Based on data analysis and hypothesis testing that have been carried out in this study, the results showed that there was a significant effect between job satisfaction on performance. Job satisfaction has an important role in improving teacher performance. According to Ahmadiansah (2016) individual job 
satisfaction and dissatisfaction will affect individual performance which will ultimately affect the achievement of organizational goals. Teacher job satisfaction is the attitude of a teacher towards his work as a pleasant or unpleasant thing based on the suitability between what is given and what is obtained. When the teacher has high job satisfaction, it means that the teacher generally likes and appreciates his work and has positive feelings about his work.

f. The Effect of Work Climate (X1) on Performance (Z) through Job Satisfaction (Y)

Based on data analysis and hypothesis testing that have been carried out in this study, the results showed that there was an indirect effect between work climate on performance through job satisfaction. The work climate is a place where teachers interact and have activities in their daily lives, therefore teachers cannot be separated from the close influence of the surrounding environment. According to Eliyanto (2018) environmental conditions are said to be good if the teacher can carry out activities optimally, healthy, safe, and comfortable. The suitability of the work environment can provide its own job satisfaction for teachers. If the work climate has a good quality, comfortable and pleasant, it will lead to satisfaction for a teacher, and this will trigger the teacher's enthusiasm in teaching which will have an impact on improving teacher performance.

g. The Effect of Work Motivation (X2) on Performance (Z) through Job Satisfaction (Y)

Based on data analysis and hypothesis testing that have been carried out in this study, the results showed that there was an indirect effect between work motivation on performance through job satisfaction. Motivation can be interpreted as a condition or action that encourages teachers to do their job as much as possible. According to Purnamasari (2018), teachers who have low motivation will tend to display feelings of discomfort and displeasure with their work, of course, this will have an impact on low teacher performance.

The motivation of each teacher in carrying out their duties is different because essentially every teacher has different motivations at work. Work motivation for teachers greatly influences the teacher's desire to do his work at school. This motivation can come from within the teacher himself or from outside. The seriousness and discipline of teachers in teaching will make teachers give their best in carrying out their duties and teachers will be encouraged to become better and work optimally which will later encourage efforts to fulfill satisfaction and desires. If the teacher is satisfied, the teacher will work with enthusiasm, and it will have an impact on improving teacher performance.

\section{Conclusion}

Based on the results of descriptive analysis, work climate, work motivation, job satisfaction and teacher performance are in the high category. Work climate and 
work motivation have a direct effect on job satisfaction of State Junior High School teachers in Bengkalis Regency. Factors that affect job satisfaction are the work climate, the suitability of the work environment can provide job satisfaction for teachers. If the teacher is satisfied, then the teacher will work with enthusiasm. Work climate, work motivation, and job satisfaction have a direct effect on the performance of State Junior High School teachers in Bengkalis Regency. Factors that affect performance are work climate, work motivation, and job satisfaction. If the work environment can support a teacher to do a better job, it will foster teacher work motivation and be more enthusiastic in carrying out his work. Teachers who are satisfied will have high morale, and of course will have an impact on high performance. Work climate and work motivation have an indirect effect on teacher performance through job satisfaction. If the work environment has good quality, is comfortable and pleasant, it will increase the satisfaction of a teacher, and this will trigger the teacher's enthusiasm in teaching which will have an impact on improving teacher performance. If the teacher is satisfied, the teacher will work with enthusiasm, and it will have an impact on improving teacher performance.

\section{References}

Ahmadiansah, R. (2016). Pengaruh motivasi kerja dan kepuasan kerja terhadap kinerja guru SMK Muhammadiyah Salatiga. INJECT (Interdisciplinary Journal of Communication), 1(2), 223-236.

Armani, A. R., \& Margunani, M. (2017). Pengaruh Profesionalisme Guru, Disiplin Kerja dan Lingkungan Kerja terhadap Kinerja Guru Mata Pelajaran Ekonomi di SMA Negeri se-Kabupaten Sragen. Economic Education Analysis Journal, 6(1), 70-82.

Badawi, A. (2014). Pengaruh Lingkungan Kerja, Disiplin Kerja, dan Motivasi Kerja terhadap Kepuasan Kerja serta Implikasinya pada Kinerja Guru. Kontigensi: Scientific Journal of Management, 2(1), 17-27.

Desmita, Y., Suarman., \& Gimin. Pedagogic and Professional Competencies of Social Science Subject Teachers in Relation to Motivation and Learning Achievement. Journal of Educational Sciences, 5(1), 188-197.

Eliyanto. (2018). Pengaruh Motivasi Kerja dan Lingkungan Kerja Terhadap Kinerja Guru SMA Muhammadiyah di Kabupaten Kebumen. Jurnal Pendidikan Madrasah, 3(1), 169-181.

Febriana, N., Syakdanur., \& Indrawati, H. (2020). The Influence of Leadership and Achievement Motivation on the Performance of Social Sciences Teachers at Private Junior High School Pekanbaru. Journal of Educational Sciences, 4(4), 785-801.

Naziah, R., Caska., Nas, S., \& Indrawati, H. (2020). The Effects of Contextual Learning and Teacher's Work Spirit on Learning Motivation and Its Impact on Affective Learning Outcomes. Journal of Educational Sciences, 4(1), 30-43.

Pamungkas, W., \& Jabar, C. S. A. (2014). Pengaruh Profesionalitas, Kepuasan Kerja Dan Iklim Organisasi Terhadap Kinerja Guru SMKN Di Kabupaten Boyolali. Jurnal Akuntabilitas Manajemen Pendidikan, 2(2), 265-278. 
Purnamasari, D. (2018). Pengaruh Lingkungan Kerja Dan Disiplin Kerja Terhadap Kepuasan Kerja Guru Sekolah Menengah Kejuruan (Smk) Swasta Sekecamatan Pondok Aren. Jurnal Saintika Unpam: Jurnal Sains dan Matematika Unpam, 1(1), 108-132.

Setiawan, E. (2018). Kompetensi pedagogis \& profesional guru PAUD dan $S D / M I$. Jakarta: Erlangga.

Siagian, S. P. (2009). Kiat Meningkatkan Produktivitas Kerja. Jakarta: Rineka Cipta.

Sulaefi. (2018). Pengaruh Disiplin, Motivasi, Budaya Organisasi dan Stres Terhadap Kepuasan Kerja Pendidik di Kabupaten Brebes. Jurnal Manajemen, 22(2), 186-204.

Sumarno. (2012). Manajemen Pengetahuan untuk Meningkatkan Mutu Sekolah. Jurnal Pendidikan Ekonomi dan Bisnis, 4(02), 8993.

Supardi. (2014). Kinerja Guru. Jakarta: PT. Raja Grafindo Persada.

Sutrisno. (2008). Manajemen Sumber Daya Manusia. Jakarta: Kencana Perdana Media Group.

Syahza, A. (2013). Dampak Kebijakan Sertifikasi terhadap Kinerja Guru di Daerah Riau. Jurnal Pendidikan, 4(2), 72-83.

Heryanto, I., \& Triwibowo, T. (2018). Path Analysis Menggunakan SPSS dan Excel. Bandung: Informatika.

Utami, P. P. (2017). Pengaruh Iklim Kerja, Kepuasan Kerja, Disiplin Kerja Terhadap Kinerja Guru SMAN se-Kota Bekasi. Visipena, 8(1), 17-32.

How to cite this article:

Miranda, M., Syahza, A., \& Sumarno. (2021). Analysis of Factors Affecting Teacher Performance in State Junior High School Learning in Bengkalis Regency. Journal of Educational Sciences, 5(3), 464-478. 